\title{
ANALISA KRITERIA TERHADAP PEMILIHAN SUPPLIER BAHAN BAKU DENGAN \\ PENDEKATAN ANALYTICAL HIERARCHY PROCESS (AHP) \\ (STUDI KASUS : PT XX PANDAAN PASURUAN)
}

\author{
Achmad Khusairi ${ }^{1,}$ Misbach Munir ${ }^{2}$ \\ ${ }^{1}$ Mahasiswa Program Studi Teknik Industri Fakltas Teknik Universitas Yudharta Pasuruan \\ ${ }^{2}$ Dosen Program Studi Teknik Industri Fakltas Teknik Universitas Yudharta Pasuruan
}

\begin{abstract}
ABSTRAK
Alternatif strategi yang bisa digunakan untuk mencapai keunggulan bersaing adalah dengan memperbaiki manajemen rantai pasokan. Salah satu tahapan dalam manajemen rantai pasokan adalah memilih pemasok. Pemasok adalah komponen yang penting untuk dipertimbangkan dalam manajemen rantai pasokan. Pemillihan pemasok yang akan digunakan perusahaan merupakan hal yang penting untuk mencapai keunggulan bersaing, karena berkaitan dengan kemampuan memasok dan menyediakan pengiriman yang singkat, dan kontinuitas produksi. Pemilihan pemasok yang tepat sangat diperlukan karena menyangkut keberlanjutan usaha yang dijalankan. Dalam merancang sistem rantai pasokan, beberapa hal yang dipertimbangkan dalam memilih pemasok, diantaranya kualitas barang yang ditawarkan, harga barang, dan ketepatan waktu pengiriman. Dari hal tersebut diatas maka rumusan masalahnya adalah bagaimana mengidentifikasi Kriteria-kriteria dalam menentukan suppliyer yang baik buat pemilihan pemasok bahan baku di PT. XX, sehingga tujuan penelitian ini adalahuntuk mengetahui kriteria dalam menentukan suppliyer yang baik sebagai pemasok bahan baku di perusahaan PT.XX.

Dalam prosesnya strategi manajemen rantai pasok memiliki tiga tujuan, yaitu :1).Menurunkan biaya, strategi manajemen rantai pasok yang diterapkan harus mampu menurunkan biaya logistik yang terjadi.2).Menurunkan modal, strategi ditujukan untuk meminimalisasi tingkat investasi dalam strategi logistik.3).Meningkatkan pelayanan, startegi manajemen rantai pasok harus secara proaktif dijalankan salah satunya yaitu perbaikan pelayanan. Faktor-faktor yang harus diperhatikan dalam pemilihan pemasok, yaitu :Kualitas, Biaya, Ketepatan Pengiriman dan Fleksibilitas. Pengolahan dan analisis data menggunakan analisis deskriptif dan analytic hierarchy process (AHP). Analisis deskriptif merupakan gambaran perkembangan karakteristik ekonomi sosial suatu daerah atau perusahaan. Analisis deskriptif digunakan untuk memperoleh gambaran kondisi rantai pasokan di perusahaan, dan kriteria-kriteria yang digunakan untuk memilih pemasok Sedangkan AHP digunakan untuk menemukan kriteria pemasok yang terbaik yaitu kriteria pemasok yang memiliki rata-rata skor paling tinggi dengan mempertimbangkan tingkat kepentingan kriteria-kriteria yang dianggap mempengaruhi keputusan. Dalam AHP, proses untuk mendapatkan skor tersebut diawali dengan perbandingan berpasangan (pairwise comparison) antar kriteria yang nantinya akan digunakan untuk mendapatkan tingkat kepentingan relatif tiap kriteria.Selanjutnya dilakukan perbandingan berpasangan antar alternatif keputusan pada masing masing faktor untuk mendapatkan kepentingan relative antar alternatif pada setiap kriteria (criteria evaluation). Data yang diperoleh dengan menggunakan AHP diolah dengan menggunakan rancangan penilaian dengan menggunakan model Quality, Quantity, Cost, dan Delivery (QQCD).

Dari hasil perhitungan dengan keputusan penilaian kerja supplier dapat dihasilkan ada keputusan yang mana supplier A dengan dengan total nilai 10 dengan keputusan menjadi supplier unggulan, supplier B degan total nilai 8,3 dengan keputusan tetap menjadu supplier, supplier $\mathrm{C}$ dengan total nilai 7,25 dengan keputusan tetap menjadi supplier, supplier D dengan total nilai dengan nilai 6 dengan keputusan surat protes (complain), dan supplier $\mathrm{E}$ dengan total nilai 5 dengan keputusan di eliminasi dari daftar supplier terpilih.
\end{abstract}

Kata Kunci : Supplier, Kriteria, AHP 


\section{PENDAHULUAN}

\section{Latar Belakang}

Alternatif strategi yang bisa digunakan untuk mencapai keunggulan bersaing adalah dengan memperbaiki manajemen rantai pasokan. Salah satu tahapan dalam manajemen rantai pasokan adalah memilih pemasok. Pemasok adalah komponen yang penting untuk dipertimbangkan dalam manajemen rantai pasokan. Pemillihan pemasok yang akan digunakan perusahaan merupakan hal yang penting untuk mencapai keunggulan bersaing, karena berkaitan dengan kemampuan memasok dan menyediakan pengiriman yang singkat, dan kontinuitas produksi. Pemilihan pemasok yang tepat sangat diperlukan karena menyangkut keberlanjutan usaha yang dijalankan. Ketika merencanakan sebuah sistem rantai pasokan, ada hal-hal yang dipertimbangkan untuk memilih pemasok, diantaranya kualitas produk bahan yang ditawarkan, harganya, dan ketepatan waktu kirim (Pujawan, 2005).

Perusahaan-perusahaan, khususnya perusahaan jenis manufaktur, selalu menjalin kerjasama dengan penyedia bahan produk guna mendapat jaminan ketersediaan bahan baku. Sejumlah perusahaan dihadapkan pada beberapa pilihan pemasok, dimana pemasok tersebut memiliki criteria dan system yang berbeda. Sehingga terjadilah proses pemilihan pemasok.Pemilihan pemasok merupakan proses pengambilan keputusan yang memerlukan analisa, karena pemilihan pemasok yang tepat akan secara langsung menghemat biaya pembelian dan meningkatkan kompetitif perusahaan.

Perusahaan yang dapat memadukan dengan baik antara strategi, teknologi, dan sumber daya yang ada, akan dapat bertahan dengan baik dalam persaingan dengan perusahaan yang bergerak di bidang industri yang sama. Banyak perusahaan kecil maupun besar yang ingin mengembangkan usahanya, tidak terkecuali pada perusahaan yang bergerak di bidang general contractor maupun pengadaan barang. Pada dasarnya setiap perusahaan mempunyai orientasi bisnis yang sama; yaitu menghasilkan profit atau keuntungan yang maksimal dengan meminimalkan biaya yang dikeluarkan. Hal tersebut dapat terwujud dengan pemilihan supplier atau pemasok yang yang sesuai spesifikasi. Supplier merupakan patner bisnis yang memegang peranan penting dalam menjamin ketersediaan material pasokan yang dibutuhkan oleh perusahaan. Kinerja supplier akan mempengaruhi performansi atau kinerja perusahaan. Oleh karena itu, perusahaan perlu menilai supplier atau pemasok secara cermat dan tepat. Evaluasi pemilihan pemasok merupakan kegiatan yang berperan strategis, terutama apabila pemasok tersebut akan memasok komponen bahan baku yang penting dan akan digunakan untuk kebutuhan jangka panjang.

PT. XX merupakan perusahaan yang bergerak di bidang manufacturing. Selain itu, PT. XX tidak memproduksinya sendiri melainkan harus mencari supplier atau pemasok lain yang memiliki stok barang yang sesuai dengan permintaan perusahaan. PT. XX menerima supplier dari beberapa daerah seperti, Itochu (Tokyo), PT. Pahala Bahri nusanta (Jakarta), CV. Wirawinda Laut Nusantara (Bnyuwangi), PT. Sari Malugis (Biting, Sulawesi Selatan), PT. Okhisin (Flores), PT. Anugrah Samudra Hindia (Sumata Utara). PT. Kelola Mina Laut (Gersik), PT. Samudra Sakti Sepakat (Ambon), PT. Caryinna Trijaya Makmur (Bitung), PT. Ocean Mitromas (Jakarta), Jepang, Arab Saudi, Afrika dan Amerika. Selama ini pemilihan pemasok agak sulit dilakukan karena semua pemasok belum mampu untuk memenuhi kebutuhan bakan baku yang baik dan pihak perusahaan belum juga menentukan kriteria-kriteria yang baik untuk pemilihan supplier adakalanya suatu pemasok mempunyai kinerja yang baik dalam hal proses 
pengirimannya, tetapi di sisi lain kurang dalam hal kualitas dibandingkan dengan pemasok lain dan sebaliknya. Untuk itu, perlu dikembangkan metode penilaian untuk melakukan seleksi dan evaluasi terhadap kinerja pemasok terutama untuk pemasok bahan baku agar dapat dilakukan secara lebih terstruktur dan transparan, sehingga para pemasok dapat memahami dasar pemilihan tersebut dan merasa diperlakukan dengan adil.

\section{Rumusan Masalah}

Bagaimana mengidentifikasi Kriteria-kriteria dalam menentukan suppliyer yang baik buat pemilihan pemasok bahan baku di PT. XX?

\section{Tujuan Penelitian}

Mengetahui kriteria dalam menentukan suppliyer yang baik sebagai pemasok bahan baku di perusahaan PT.XX.

\section{Manfaat Penelitian}

A.Bagi Akademisi

Sebagai bahan pengembangan keilmuan dalam pencapaian produktifitas perusahaan dan sebagai upaya dalam peningkatan prifit perusahaan.

\section{B.Bagi Praktisi}

Sebagai bahan rekomendasi perusahaan dalam penentuan kriteria suppliyer yang baik dan memiliki loyalitas terhadap perusahaan.

\section{TINJAUAN PUSTAKA}

Penelitian Terdahulu

$$
\text { Ninik Wulandari (2014) meneliti, }
$$

Perancangan Sistem Pendukung Keputusan Pemilihan Supplier di PT. Alfindo Dengan Metode Analytical Hierarchy Process (AHP). PT. Alfindo merupakan perusahaan yang bergerak di bidang contractor, fabrikasi, manufacturing, general trading, and labour supply. PT. Alfindo tidak memproduksi barang sendiri melainkan membutuhkan supplier dalam proses pengadaan barang. Namun, dalam proses pemilihannya PT. Alfindo masih mengalami kesulitan dalam memilih supplier yang terbaik, perusahaan juga belum memiliki kriteria khusus dalam melakukan penilaian terhadap supplier, serta membutuhkan waktu yang lama dalam proses pemilihannya. Penelitian ini bertujuan untuk menghasilkan suatu rancangan aplikasi yang dapat digunakan untuk pemilihan supplier, dan dapat membantu dalam memberikan evaluasi terhadap supplier berdasarkan kriteria yang dimiliki perusahaan, diantaranya harga, kualitas, pelayanan, waktu pengiriman, dan responsibilitas, serta dapat mengefisienkan waktu dalam pembuatan laporan. Penelitian dilakukan dengan metode observasi, wawancara, dan studi pustaka. Penelitian dilakukan di PT. Alfindo Banten Sukses Bersama. Sistem dirancang dengan menggunakan metode Analytical Hierarkhi Process (AHP) sebagai perhitungannya dan menggunakan Unified Modelling Language (UML) sebagai model perancangannya. Adapun software yang digunakan untuk membangun sistem ini adalah menggunakan Hypertext Preprocessor (PHP) dengan MySQL Server sebagai database-nya. Dari penilitian yang telah dilakukan maka dihasilkan sebuah sistem pendukung keputusan pemilihan supplier di PT. Alfindo dengan metode Analytical Hierarkhi Process (AHP), untuk membantu dalam proses pemilihan supplier terbaik sebagai pemasok barangbarang atau spare part alat kebutuhan industri yang dibutuhkan konsumen.

Widya Teknika (2012) meneliti, pemilihan baku pengemas dengan metode AHP (Analytical Hierarchi Process). Globalisasi di tuntut suatu perusahaan memiliki tingkat daya saing tinggi, setiap pelaku bisnis yang ingin memenangkan kompetisi dalam dunia industri akan memberikan perhatian penuh pada efektivitas dan efisiensi perusahaan, termasuk dalam masalah logistik. Dengan pendekatan metode Analytical Hierarchy Process (AHP), dilakukan pemilihan supplier bahan baku pengemas pada perusahaan. Hasil penilaian evaluasi kinerja supplier diperusahaan 
menggunakan rancangan penilaian dengan menggunakan model Quality, Quantity, Cost, dan Delivery (QQCD) menghasilkan 4 Supplier Performance Indicator (SPI). Kriteria quality memiliki bobot yang tertinggisebesar $40 \%$, Delivery sebesar 30\% selanjutnya Quantity 20\% dan terakhir adalah cost atau harga sebesar $10 \%$.Hasil keputusan penilaian tetap dijalankan oleh perusahaan meskipun hasil keputusannya adalah mengeluarkan supplier dari daftar supplier terpilih.

\subsection{Pengertian Supply Chain Management}

\subsection{Rantai Pasok dan Manajemen Rantai Pasok}

Rantai pasokan adalah suatu sistem tempat organisasi menyalurkan barang dan jasanya kepada para pelanggannya. Rantai ini juga merupakan jaringan dari berbagai organisasi yang saling berhubungan dan mempunyai tujuan yang sama, yaitu menyelenggarakan pengadaan atau penyaluran barang tersebut. Model rantai pasokan yaitu suatu gambaran mengenai hubungan mata rantai dari pelaku-pelaku tersebut yang dapat membentuk seperti mata rantai yang terhubung satu dengan yang lain. Salah satu faktor kunci untuk mengoptimalkan rantai pasok adalah dengan menciptakan alur informasi yang bergerak secara mudah dan akurat diantara jaringan tersebut, dan pergerakan barang yang efektif dan efisien yang menghasilkan kepuasan pelanggan.

Manajemen rantai pasokan merupakan strategi alternatif yang memberikan solusi dalam menghadapi ketidakpastian lingkungan dalam keunggulan kompetitif melalui pengurangan biaya operasi dan perbaikan pelayanan konsumen serta kepuasan konsumen. Manajemen rantai pasokan menawarkan suatu mekanisme yang mengatur proses bisnis dan meningkatkan produktifitas.

Menurut Heizer dan Render (2010), manajemen rantai pasokan merupakan penyatuan kegiatan pengadaan komponen material produk dan system pelayanaan, produksi barang setengah jadi sampai produk akhir, serta pengiriman sampai ke pelanggan. Kegiatan-kegiatan tersebut dimulai dari kegiatan pembelian sampai proses produksi suatu produk, serta menjalin komunikasi antara pemasok dengan perusahaan. Tujuan dari seluruh aktivitas rantai pasokan adalah mengkomunikasikan secara system dalam menjalin kerjasama untuk mengedepankan pelayanan pelanggan.

Ruang lingkup manajemen rantai pasok meliputi:

1. Rantai pasokan yang mencakup seluruh kegiatan arus dan transformasi barang mulai dari bahan mentah, sampai penyaluran ketangan konsumen termasuk aliran informasinya. Bahan baku dan aliran informasi adalah rangkaian dari rantai pasokan.

2. Rantai pasokan sebagai suatu sistem tempat organisasinya menyalurkan barang produksi dan jasa kepada para pelanggannya

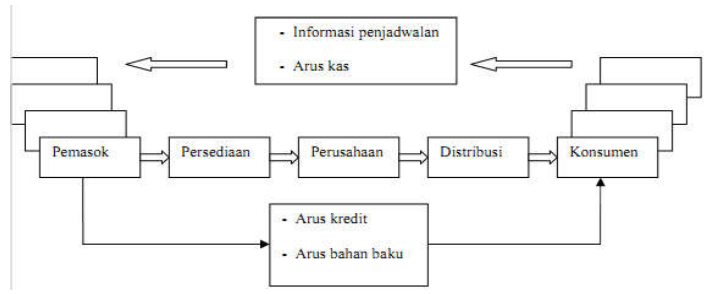

Gambar 2.1 Struktur Manajemen Rantai Pasokan

Sebuah rantai pasokan sederhana memiliki komponen- komponen yang disebut channel yang terdiri atas pemasok, manufaktur, distribution centre, wholesaler dan retailer yang semuanya bekerja menuju proses akhir. Sebuah rantai pasok bisa saja melibatkan sejumlah industri manufaktur dalam suatu rantai hulu ke hilir. Tidak selamanya sebuah rantai pasok berupa rantai lurus (Anatan dan Elitan, 2008).

\subsection{Strategi Manajemen Rantai Pasokan}

Pujawan (2005) mendefinisikan strategi rantai pasok sebagai kumpulan kegiatan dan aksi strategis 
di sepanjang rantai pasok yang menciptakan rekonsiliasi antara apa yang dibutuhkan pelanggan akhir dengan kemampuan sumberdaya yang ada pada rantai pasok tersebut. Tujuan strategis rantai pasok adalah menghasilkan produk yang murah, berkualitas, tepat waktu, dan bervariasi.

Dalam prosesnya strategi manajemen rantai pasok memiliki tiga tujuan, yaitu :

1.Menurunkan biaya, strategi manajemen rantai pasok yang diterapkan harus mampu menurunkan biaya logistik yang terjadi.

2.Menurunkan modal, strategi ditujukan untuk meminimalisasi tingkat investasi dalam strategi logistik.

3.Meningkatkan pelayanan, startegi manajemen rantai pasok harus secara proaktif dijalankan salah satunya yaitu perbaikan pelayanan.

2.5 Pengukuran dan Evaluasi Performansi Rantai Pasok

Menurut Marimin dan Maghfiroh (2010) mengukur adalah aktifitas untuk menentukan luas, dimensi, kuantitas, atau kapasitas suatu objek yang umumnya dibandingkan terhadap suatu standar. Tujuan pengukuran dalam penelitian adalah menyediakan data dengan kualitas sebaik mungkin dan kesalahan sekecil-kecilnya untuk menguji hipotesis, melakukan estimasi, prediksi, atau deskripsi. Pengukuran dalam penelitian merupakan proses yang terdiri dari 3 bagian :

a.Menentukan peristiwa atau percobaan yang dapat diamati oleh indra (pengamatan empiris)

b. Menggunakan variabel atau simbol yang bisa berupa angka atau nilai untuk mewakili komponen-komponen percobaan yang dilakukan.

c.Memberikan hubungan anatara variabel yang dibuat dan pengamatan yang dilakukan.

Pemilihan Pemasok Dalan Supply Chain

Memilih rekanan atau seleksi penjualatau pemasok barang, yang kadang-kadang juga disebut pencarian sumber pembelian atau sourching, merupakan bagian yang penting dalam proses pembelian. Baik bagi perusahaan yang pembeliannya diatur oleh aturan perusahaan atau tidak, kegiatan tersebut tetap merupakan kegiatan yang sangat penting. Satu hal yang dapat dikemukakan disini ialah bahwa sebagaimana evaluasi pada umumnya, evaluasi pemasok dapat dilaksanakan secara kualitatif dan kuantitatif. Walaupun keduanya memiliki orientasi yang berbeda, umumnya pendekatan kuantitatif, karena lebih objektif dan lebih dapat dipertanggungjawabkan. Disamping itu pembahasan mengenai evaluasi pemasok yang akan dilakukan di sini bertitik tolak dari dua pandangan dalam mencari sumber pemebelian, yaitu:

$>$ Sumber banyak, yang makin lama makin ditinggalkan

$>\quad$ Sumber tunggal, yang makin lama makin popular

Sebelumnya perlu dijelaskan bahwa harus dibedakan antara sumber tunggal atau single sourcing dan sumber satu-satunya sole sourching, karena keduanya sepintas lalu sama, tetapi sebetulnya sangat berbeda maknanya.

○ Sumber satu-satunya

Sumber satu-satunya adalah yang memang hanya satu-satunya yang tersedia dan tidak ada pilihan lain selain menggunakan sumbern yang satu ini. Dengan perkataan lain, terjadi monopoli, dan pembeli terpaksa membeli dari sumber satu ini karena tidak ada jalan lain. Dalam hal ini cara-cara pemilihan pemasok tidak relevan lagi untuk di bicarakan karena pembeli tidak bisa berbuat banyak kecuali menerima. Usaha yang dapat dilakukan oleh pembeli adalah mencari sumber alternative agar terhindar dari situasi monopoli ini.

\section{○ Sumber Tunggal}

Sumber tunggal adalah keadaan dimana sebetulnya ada cukup banyak sumber pengadaan yang tersedia di pasaran, namun melalui satu cara 
metode, dan seleksi tertentu, dipilih satu saja sebagai satu sumber tunggal. Dengan demikian, dalam sumber tunggal tidak ada sumber keterpaksaan dari pihak dari pihak pembeli, karena pemilihan dilakukan dengan sengaja dan dengan perencanaan sebelumnya berdasarkan alasan-alasan tertentu. Praktik ini dilakukan dalam rangka mencari rekan mitra kerja untuk melaksanakan apa yang disebutkemitraan pembeli-penjual. Oleh karena itu, sumber tunggal tidak dapat disebut sebagai monopoli, dalam pengertian sifat-sifat buruk monopoli tidak terbawa dalam cara ini. Dalam praktik, sumber tunggal dapat juga sedikit berkembang dan tidak mutlak berarti satu sumber pembelian saja, tetapi dapat dua atau tiga, yang penting adalah sumber pembelihanya sangat terbatas.

\subsection{Evaluasi Kinerja Pemasok}

Setelah pemasok dipilih dan hubungan antara pembeli penjual telah cukup perkembangan, dalam arti telah ada hubungan jual beli untuk beberapa waktu lamanya, maka tibalah kegiatan penting lagi bagi pembeli profisional, yaitu mengenai "Evaluation of supplier performance", national association of purchasing management (NAPM) melakukan investigasi tentang tiga tipe perencanaan evaluasi pemasok, yaitu :

\section{Categoriel Plant}

Dalam perencanaan ini, beberapa petugas dari berbagai bagian perusahaaan pembeli memuat catatan evauasi secara informal. Mereka yang besangkut disini adalah yang bekerja dibagian pemebelian, rekayasa, pengenalian mutu, akutansi dan pergudangan (penerimaan). Untuk setiap pemasok besar, setiap petugas tersebut membuat daftar factor kinerja yang penting bagi mereka masing-masing. Pada setiap pertemuan bulanan, setiap pemasok besar dinilai berdassrakan faktor kinerja yang sudah disiapkan. Setiap factor tersebut ditimbang secukupnya secara relative, dan setiap pemasok dinilai secara keseluruhan, yang biasanya dikategorikan dalam tiga golongan besar, yaitu :
a. Preferred
b. Neutral
c. unsantisfactory

\section{The weighted point plan}

Di dalam perencanaan ini, factor kinerja yang dinilai besar bobot. Misalnya, dalam suatu pertimbangan tertentu, mutu diberi bobot $25 \%$ layanan 25\% dan harga 25\%. Dalam hal ini, munkin diberi bobot $50 \%$ dan layanan berkurang menjadi 25\%. Pemberian imi memamng perlu di pertimbangkan dan ditentukan oleh pembeli berdasarkan perkiraan tingkat kepentingan relative dari masing-masing pemasok berdasarkan pembobotan.

\section{3. cost ration plan}

Dalam cara ini, kinerja pemasok dinilali dengan menggunakan analisis harga standar. Jika menggunakan cara ini, pembeli harus menghitung tambahan biaya yang terjadi apabila memebeli dari pemasok tertentu. Ini terpisah dari tiga faktor kinerja yang disebut diatas, yaitu mutu, layanan, dan harga. Tiap-tiap tambahan biaya factor tersebut diterjemahkan dalam "rasio" sehingga ada tiga jneis rasio biaya. Selanjutnya, tiga jenis rasio biaya ini dijumlahkan menjadi jumlah rasio biaya untuk pemasok tertentu

\subsection{Pemilihan Pemasok Dalan Supply Chain}

Pemilihan pemasok dalam rangka rantai pasokan tidak jauh berbeda dengan yang sudah dijelaskan di atas, perbedaan yang utama ialah bahwa pemasok dalam rnagka pemikiran rantai pasokan mempunyai kedudukan yang jauh lebih penting, menjadi mitra dan aliansi strategis, mempunyai hubungan jangka panjang, diandalkan riset dan pengembangan produknya, dan diharapkan terus menerus melakukan perbaikan dalam mutu dan harga barang.Faktor-faktor yang harus diperhatikan dalam pemilihan pemasok, yaitu : 
a.Kualitas (Quality)

Kriteria kualitas yang dimaksudkan di sini adalah kemampuan pemasok menghasilkan produk yang berkualitas. Jika pemasok bisa menghasilkan produk yang berkualitas, maka pelanggan akan loyal terhadap produk tersebut karena pelanggan mendapatkan kepuasan.

b. Biaya (Cost)

Kriteria biaya bahan baku yang dipasok oleh pemasok merupakan kriteria finansial yang menjadi pertimbangan setiap pabrik dalam memilih pemasok. Kriteria biaya bahan baku dalam hal ini mencakup seluruh faktor yang berbau finansial yaitu harga bahan serta biaya pengiriman.Harga dan biaya pengiriman akan berpengaruh terhadap produk yang akan diproduksi dan berkaitan dengan harga pokok penjualan.

\section{c. Ketepatan pengiriman (Delivery)}

Kriteria ini menilai pemasok dari segi pelayanan pengiriman bahan baku, baik mengenai ketepatan waktu pengiriman maupun ketepatan jumlah yang di order.. Ketepatan jumlah bahan baku yang dikirim serta waktu pengiriman juga perlu diprioritaskan dan harus tepat waktu, tepat jumlah dan tepat sasaran sehingga tidak mengganggu aktifitas produksi.

\section{d. Flexibility}

Kriteria ini menilai pemasok dari segi kemampuan pemasok memenuhi permintaan terhadap perubahan jumlah dan waktu. Kriteria ini berhubungan dengan performance dari pemasok bahan baku.

\subsection{Analytical Hierarchy Process (AHP)}

AHP pada dasarnya didesain untuk menangkap secara rasional persepsi orang yang berhubungan dengan permasalahan tertentu melalui prosedur yang didesain untuk sampai pada suatu skala preferensi diantara berbagai alternatif. Konsep metode AHP sebenarnya adalah merubah nilai-nilai kualitatif menjadi nilai kuantitatif.
Sehingga keputusan-keputusan yang diambil bisa lebih obyektif. AHP merupakan analisis yang digunakan dalam pengambilan keputusan dengan pendekatan sistem, dimana pengambil keputusan berusaha memahami suatu kondisi sistem dan membantu melakukan prediksi dalam mengambil keputusan. Dalam metode ini, ada tiga prinsip dalam memecahkan persoalan dengan analisa logis eksplisit, yaitu:

\section{Penyusunan Hirarki}

Analisis terhadap faktor - faktor tersebut dalam AHP dilakukan dengan membuat struktur hirarki. Hirarki yang dihasilkan dapat berupa hirarki lengkap dan tidak lengkap.Untuk hasil dengan nilai akurat, pemecahan dilakukan terhadap unsur unsur pada level maupun yang dipilih sampai tidak mungkin dianalisa lagi, sehingga didapatkan beberapa tingkatan dari persoalan tadi. Proses analisis ini dinamakan hirarki. Dalam struktur hirarki lengkap, jumlah tingkatan faktor-faktor tergantung pada pemilihan peneliti, secara umum, unsur yang digunakan pada hirarki adalah faktor, aktor, tujuan, dan alternatif.

\section{Penerapan Prioritas}

Penilaian ini merupakan proses penting dalam AHP, karena memberikan pengaruh yang rinci pada penentuan prioritas unsur - unsurnya. Hasil penilaian ini lebih sesuai jika disajikan dalam bentuk matriks perbandingan berpasangan.Hasil dari penilaian ini akan disajikan dalam bentuk matriks Pairwise Comparison.

\section{Konsistensi Logis}

Sistem hierarki keputusan memiliki bentuk yang saling berkaitan, yang tersusun dari fokus, turun ke tujuan, kemudian ke pelaku, komponen sistem hirarki keputusan dalam AHP tidak memiliki prosedur yang pasti, sehingga sistem tidak harus terbentuk secara mutlak dari komponen-komponen seperti yang telah disebutkan. Fokus dalam tahap 
ini adalah komponen-komponen sistem yang dipilih dan digunakan dalam bentuk sistem hirarki yang ada. Hal ini diidentifikasikan berdasarkan kemampuan analisis dalam menemukan unsur tersebut tergantung dari penguasaan para analis terhadap persoalan. Metode AHP diperlukan untuk penentuan bobot bagi elemen di satu level yang akan berpengaruh terhadap bobot elemen pada level dibawahnya.Pada akhirnya metode AHP dapat digunakan untuk menghitung bobot pada setiap level untuk penilaian dan preferensi secara ringkas dan padat.

\section{Kegunaan Analytical Hierarchy Process (AHP)}

AHP dapat diterapkan untuk beragam masalah yang luas, dan dapat digunakan untuk jenis persoalan antara lain :

* Menetapkan prioritas

* Menghasilkan seperangkat alternatif

* Memilih alternatif kebijakan yang terbaik

* Menetapkan berbagai persyaratan

* Mengalokasikan sumberdaya

* Meramalkan hasil dan menaksir resiko

2.11 Prosedur Dalam AHP

a. Menentukan jenis-jenis kriteria yang digunakan

b. Menyusun kriteria-kriteria tersebut dalam matrik berpasangan

$$
a_{i j}=\frac{w i}{w j}, i, j=1,2, \ldots, n
$$

Dimana $\mathrm{n}$ menyatakan jumlah kriteria yang dibandingkan, wi bobot untuk kriteria ke-i dan aij adalah perbandingan bobot kriteria ke i dan j.

c.Menormalkan setiap kolom dengan cara membagi setiap nilai pada kolom ke $\mathrm{i}$ dan baris ke $\mathrm{j}$ dengan nilai total dari setiap kolom

$$
a_{i j}=\frac{a_{i j}}{\Sigma a_{i j}}
$$

d. Menentukan bobot prioritas setiap kriteria ke i, dengan membagi jumlah setiap nilai a dengan jumlah kriteria yang dibandingkan (n).

$$
w i=\frac{\Sigma a}{n}
$$

e. Menentukan WSF (Wieght Single Factor) dengan rumus

$$
a_{i j}=\Sigma_{i=1}^{n} a_{i j} \times w_{i}
$$

f. Menentukan nilai CF (Consistenci Factor) dengan rumus

$$
C F=\frac{\text { wsF }}{\text { Bobot }}
$$

g. Menghitung nilai lamda max atau CF rata-rata dengan rumus

$$
\lambda \max =\frac{\Sigma \mathrm{CF}}{n}
$$

h. Menghitung Consistensi Index (CI) Perhitungan Indeks Konsistensi menggunakan persamaan:

$$
C I=\frac{\lambda \max -n}{n-1}
$$

i. Mengukur total konsistensi nilai dengan melihat konsistensi rasio (CR) dengan rumus:

$$
C \mathrm{R}=\frac{\mathrm{CI}}{\mathrm{RI}}
$$

j. Suatu tingkat konsistensi tertentu sebagai dasar penentuan prioritas guna menghasilkan nilai yang terbaik dan menjadi acuan dalam pengambilan keputusan. Nilai $\mathrm{CR} \leq 0,10$ adalah nilai konsistensi jika tidak maka perlu dilakukan revisi.

Tabel 2.1: Nilai Random Index (RI)

\begin{tabular}{|c|c|}
\hline $\mathbf{N}$ & RT \\
\hline 1 & 0.00 \\
\hline 2 & 0.00 \\
\hline 3 & 0.58 \\
\hline 4 & 0.90 \\
\hline 5 & 1.12 \\
\hline 6 & 1.24 \\
\hline 7 & 1.32 \\
\hline 8 & 1.41 \\
\hline 9 & 1.45 \\
\hline 10 & 1.49 \\
\hline 11 & 1.51 \\
\hline 12 & 1.48 \\
\hline 13 & 1.56 \\
\hline 14 & 1.57 \\
\hline 15 & 1.59 \\
\hline
\end{tabular}

k.Penentuan nilai bobot prioritas diperoleh dari penjumlahan nilai bobot perbandingan antar kriteria dikalikan dengan nilai bobot perbandingan alternatif dengan kriteria

Bobot Prioritas $=$

$\Sigma$ (Bobot Perbandingan Antar Kriteria $\mathrm{x}$ Bobot Perbandingan Alternatif dengan Kriteria) 
Tabel 2.2 : Skala Penilaian Perbandingan Berpasangan

\begin{tabular}{|c|c|}
\hline $\begin{array}{c}\text { Intensitas } \\
\text { Kepentinganl }\end{array}$ & Keterangan \\
\hline 1 & Kedua elemen sama pentingnya \\
\hline 3 & Elemen yarg satu secikit lebih penting dari paca elemen yang lainnya \\
\hline 5 & Elemen yarg satu lebih penling dari elemen yang lainys \\
\hline 7 & Salu elemen jelas lebih mullak penting daripada elemen lainnya \\
\hline 9 & Satu elemen mutlak penting darioada elemen lainnya \\
\hline $2,4,6,8$ & 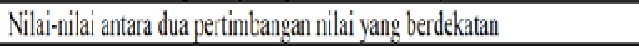 \\
\hline Kebalikan & $\begin{array}{l}\text { Jika untuk aktivitas i mendapatkan satu angka dibanding dengan altivitas } \\
\text { j, maka i mempunyai nilai kesal likannya dibanding dengan i }\end{array}$ \\
\hline
\end{tabular}

\section{METODE PENELITIAN}

Pengumpulan Data

Dalam pengumpulan data dilakukan dengan beberapa cara, antara lain :

a.Observasi, yaitu proses pengumpulan data untuk memperoleh sejumlah data dan informasi dengan melakukan pengamatan dan pencatatan.

b. Wawancara, yaitu proses pengumpulan sejumlah data dan informasi berupa keterangan dengan mengadakan komunikasi secara langsung kepada manajer atau operator untuk mengetahui hal-hal yang berhubungan dengan obyek penelitian.

c. Dokumentasi, yaitu proses pengambilan data dari perusahaan yang telah terdokumentasikan atau arsip-arsip, seperti : biaya-biaya yang terkait dengan proses produksi, fasilitas peralatan yang digunakan dalam proses supplier, serta alur proses pembelian bahan.

d. Kuisioner, yaitu lembar yang berisi petanyaan atau pernyataan yang di tujukan kepada pelaku yang berhubungan dengan pemasok bahan dan sistemnya.

\section{Pengolahan dan Analisa Data}

Pengolahan dan analisis data menggunakan analisis deskriptif dan analytic hierarchy process (AHP). Analisis deskriptif merupakan gambaran perkembangan karakteristik ekonomi sosial suatu daerah atau perusahaan. Analisis deskriptif digunakan untuk memperoleh gambaran kondisi rantai pasokan di perusahaan, dan kriteria-kriteria yang digunakan untuk memilih pemasok.

Sedangkan AHP digunakan untuk menemukan kriteria pemasok yang terbaik yaitu kriteria pemasok yang memiliki rata-rata skor paling tinggi dengan mempertimbangkan tingkat kepentingan kriteria-kriteria yang dianggap mempengaruhi keputusan. Dalam AHP, proses untuk mendapatkan skor tersebut diawali dengan perbandingan berpasangan (pairwise comparison) antar kriteria yang nantinya akan digunakan untuk mendapatkan tingkat kepentingan relatif tiap kriteria.

$$
\text { Selanjutnya dilakukan perbandingan }
$$
berpasangan antar alternatif keputusan pada masing masing faktor untuk mendapatkan kepentingan relative antar alternatif pada setiap kriteria (criteria evaluation). Data yang diperoleh dengan menggunakan AHP diolah dengan menggunakan rancangan penilaian dengan menggunakan model Quality, Quantity, Cost, dan Delivery (QQCD).

3.2 Alur Kerangka Berpikir

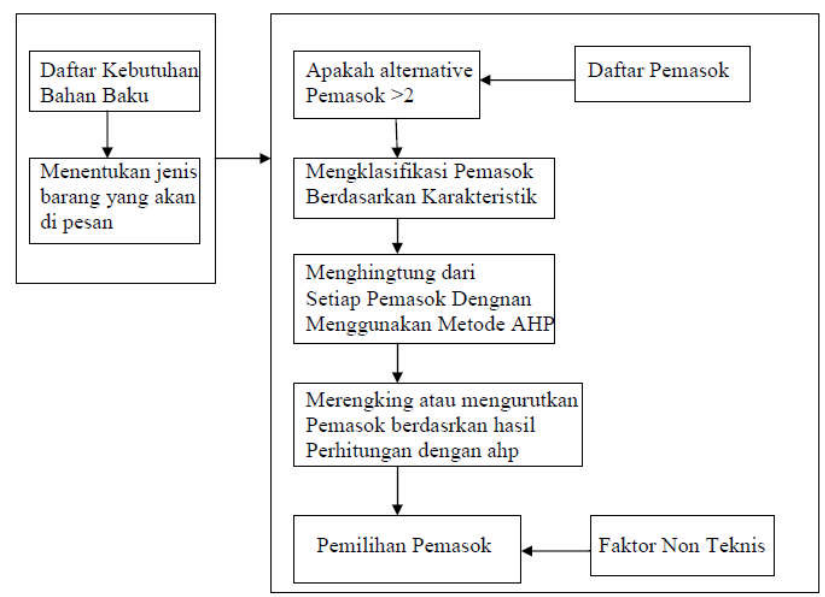

Gambar 3.1 Alur Kerangka Berpikir

Skema alur berpikir yang pertama kita lakukan adalah menentukan daftar kebutuhan bahan baku setelah itu menentukan jenis barang yang akan dipesan dan berlanjut ke daftar pemasok atau dengan alternatif yang lainnya setelah itu 
mengklasifikasi pemasok berdasarkan karakteristik pemasok. Kemudian dilanjutkan proses menghitung bobot dari setiap pemasok dengan menggunakan metode AHP setelah itu merangking pemasok berdasarkan hasil perhitungan dengan AHP dan yang terakhir pemilihan pemasok atau dengan pemilihan factor non teknis.

\section{HASIL DAN PEMBAHASAN}

\section{Pemetaan Rantai Pasokan}

Untuk melihat perilaku sistem rantai pasokan pada PT. XX secara keseluruhan, maka perlu diketahui dahulu aliran data dan material secara jelas dan terperinci. Oleh karena itu diperlukan pemetaan aliran data dan material dalam beberapa tingkatan. Tingkat pertama menggambarkan aliran data dan material dalam sistem secara umum. Tingkat kedua menggambarkan aliran yang lebih rinci, dan seterusnya sampai aliran tersebut sudah tidak dapat diperinci lagi.

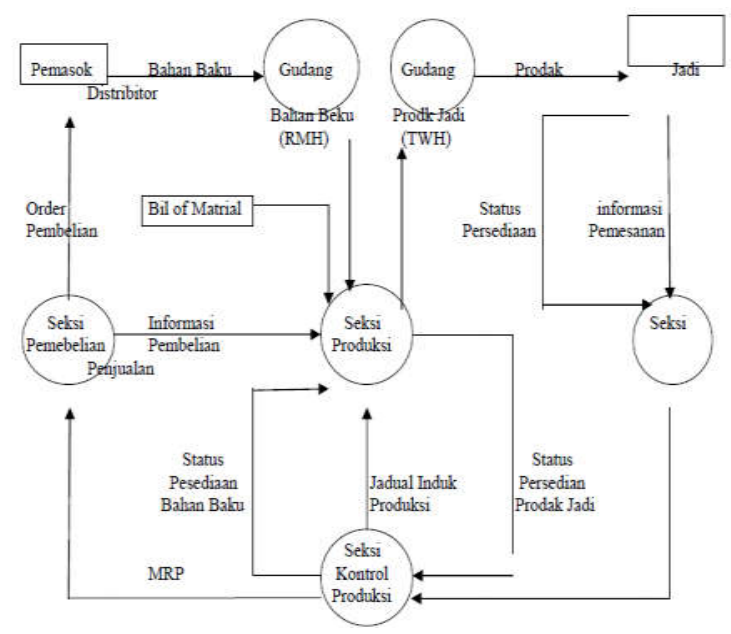

Gambar 4.1 Diagram Aliran Bahan Material

Aliran Data Material Pembelian Bahan baku

Proses pembelian bahan baku ikan tuna yang dilakukan di PT. XX dengan adanya permintaan pembelian bahan baku dari Departemen PPIC untuk kebutuhanproduksi selama 1 bulan kedepan dengan hanya adanya buffer stock bahan baku pengemas selama 1 minggupersediaan pemakaian produksi oleh karena itu Departemen pembelian benar -

benar di tuntut untuk bisa memilih supplier yang bisa diandalkan.

Permintaan pembelian yang diajukan oleh Departemen PPIC selalu di lampirkan juga dengan jadwalpermintaan kedatangan bahan baku pengemas yangharus di penuhi oleh Departemen Pembelian,Selanjutnya bagian pembelian akan membuatkonfirmasi order kepada supplier terpilih yang isinyamengenai jumlah bahan baku pengemas yang akan dibeli berikut dengan waktu kedatangan yang diminta.Supplier yang sudah menerima konfirmasi order tersebut akan segera memberikan konfirmasi mengenai kesanggupan pengiriman dan harga dari bahan baku

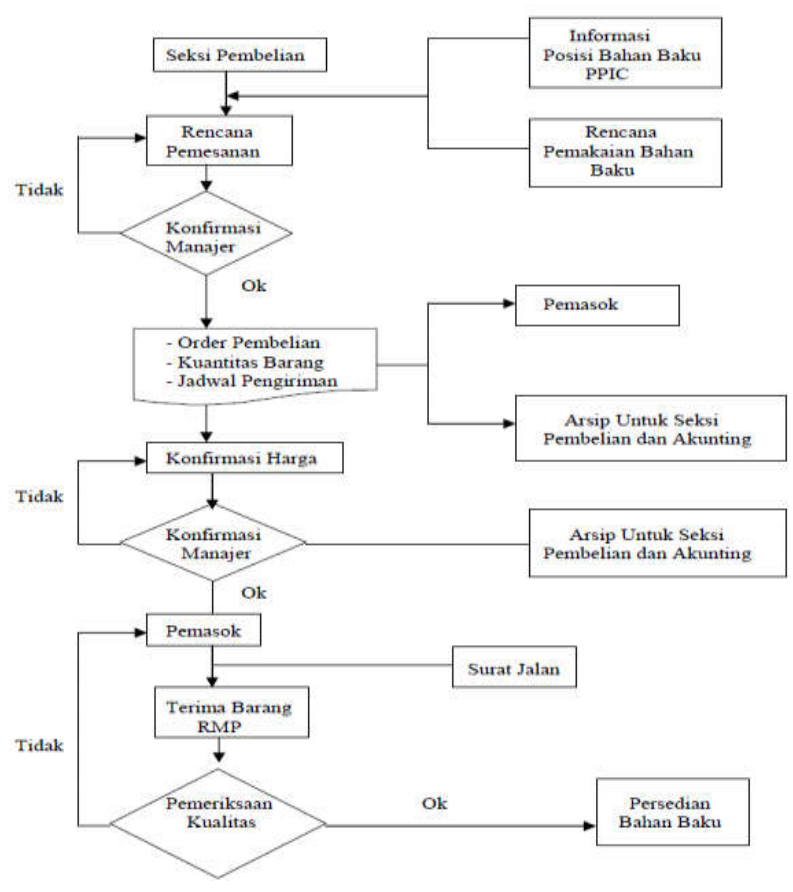

Gambar 4.2 Diagram Alir Pembelian Bahan Baku

Dari gambar diagram alir diatas
menjelaskan tentang peta aliran data dalam
pembelihan bahan baku yang di awali dengan seksi
pembelian bahan baku dengan mengetahui terlebih
dahulu informasi posisi bahan baku dan rencana
pemakaian bahan baku setelah semuanya sudah
selesai terus menuju rencana pemesanan lalu ke


konfirmasi manajer kalau sudah persetujuan dari manajer pemesanan boleh di teruskan tapi kalau mash tidak harus kembali lagi ke rencana pembelian bahan baku.

Setelah manajer setuju tahap selanjtnya keorder pembelian, kuantitas barang, jadual pengiriman tapi dengan syarat pemasok harus memebrikan arsip untuk seksi pembelian dan akunting, setelah itu tahap selanjutnya kekonfirmasi harga dengan melalui manajer tapi kalaw manajer tidak setuju dengan harga yang ditawarkan supliyer maka pemesanan bahan baku kembali lagi kekonfirmasi harga, tapi kalau manajer sudah setuju di lanjutkan lagi kepemasok dan membawa bahan baku yang akan di supply ke perusahaan dengan ketentuan diperikasa kualitas bahan baku oleh perusahaan terlebih dahulu setelah ok baru bisa di pesan oleh perusahaan tapi kalau hasil pemeriksaan kualitas bahan baku oleh perusahaan jelek maka bahan baku tersebut deikembalikan lagi ke supplier.

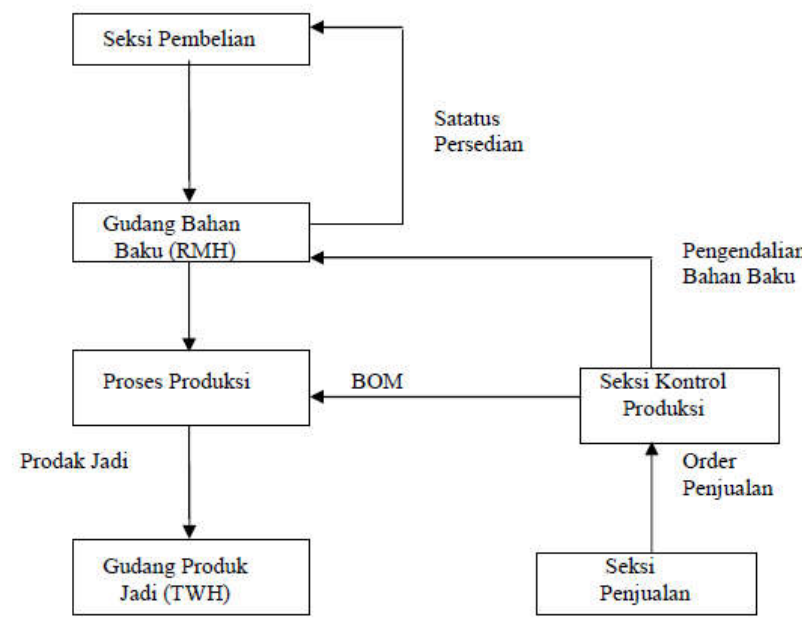

Gambar 4.3 Alur Material Tingkat Produksi

Dari gambar diagram diatas menjelaskan tentang diagram alir data material produksi yang diawali dari seksi pembelian bahan baku menuju gudang bahan baku (RMH) dengan meihat terlebih dahulu persedian bahan baku yang masih ada, kemudian menuju proses produksi, prodak jadi dan terahir meneuju gudang prodak jadi (TWH) tapi melihat itu semua tidak luput pula dari seksi penjualan prodak jadi dengan ngengntrol proses produksi dan gudang bahan baku karena tanpa melihat keduanya tersesbut seksi penjualan tidak langsung menjual hasil prodak jadi.

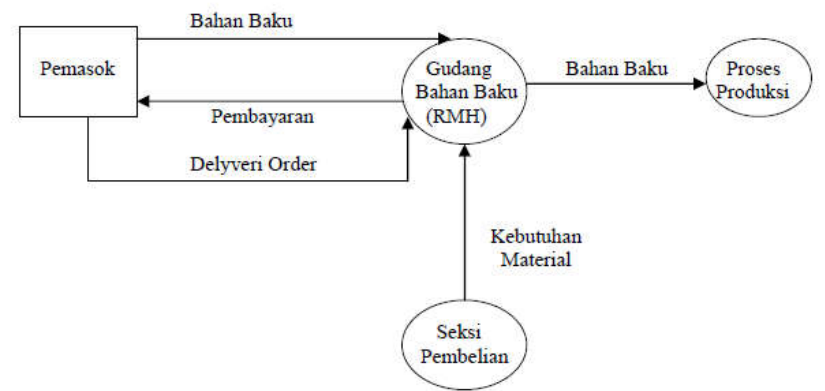

Gambar 4.3 Alur proses Inventory Material

Dari gambar diagram di atas menjelaskan tentang diagram aliran data material persedian bahan baku yang diawali dari pemasok bahan bkau menuju ke gudang bahan baku atau melalui pengiriman Order, setelah itu bahan baku diproses produksi dan juga melalui seksi pembelian bahan baku bisa dibelikan tapi dengan melihat jumlah kwantitas bahan baku yang dibutuhkan.

Pemasok Bahan Baku

Untuk pengajuan menjadi pemasok, terlebih dahulu calon pemasok mengirimkan bahan baku yang sesuai dengan spesifikasi permintaan, penawaran harga, dan meminta sample lengkap dengan analisa kualitas. Setelah mendapat persetujuan dari PT. XX, maka pemasok tersebut sudah dapat menerima PO dari PT. XX dan dengan tahap sebagai berikut :

\section{- Fase Awal}

Fase ini merupakan tahap memahami sistem pemilihan pemasok yang selama ini dilakukan oleh perusahaan, dengan mengumpulkan data pemasok material dan mempelajari proses pengirimannya.

\section{- Tahap Pemilihan Supplier}

Tahap ini merupakan tahapan yang penting dalam membangun suatu pengukuran kinerja yang terdiri dari beberapa bagian yang merupakan langkah- 
langkah dari pemilihan supplier dengan mengunakan Metode Analisis Hirarki Proses (AHP).

\section{- Tahap Pengklasifikasian Supplier}

Klasifikasi supplier bertujuan untuk menentukan kriteria penilaian pada setiap kelompok supplier. Karena barang yang dipasok oleh supplier mempunyai pengaruh yang berbeda bagi perusahaan dan mempunyai kesulitan yang berbeda pula bagi supplier untuk mendapatkannya.Tingkat kepentingan dilihat berdasarkan nilai barang yang diperolah melalui hasil perkalian harga dengan jumlah pemakaian barang tersebut. Harga barang yang tinggi menunjukan bahwa barang terebut sangat berpengaruh bagi peruisahaan jika tidak dilakukan pengendalian yang tepat.Sedangkan tingginya jumlah pemakaian menunjukan bahwa barang tersebut banyak dibutuhkan oleh perusahaan.

- Menentukan Bobot Kriteria Supplier

Untuk menentukan kriteria yang paling mempengaruhi kinerja masing-masing kelompok suppliers diatas, dapat dilihat dari bobot masingmasingnya. Bobot setiap kriteria ditentukan oleh hasil perbandingan berpasangan setiap kiteria.

Tabel 4.1 Skala Perbandingan

\begin{tabular}{|c|c|c|}
\hline Tingkat Kepentingan & Definisi & Keterangan \\
\hline 1 & Sama Pentingnya & $\begin{array}{c}\text { Kedua elemen Mempunyai } \\
\text { pengaruh yang sama. }\end{array}$ \\
\hline 3 & $\begin{array}{c}\text { Sedikit Lebih } \\
\text { Penting }\end{array}$ & $\begin{array}{c}\text { Penilaian lebih sedikit memihak } \\
\text { pada salah satu elemen } \\
\text { dibandingkan pasangannya. }\end{array}$ \\
\hline 5 & Lebih Penting & $\begin{array}{c}\text { Penilaian sangat memihak pada } \\
\text { salah satu elemen dibandingkan } \\
\text { pasangannya. }\end{array}$ \\
\hline 7 & Sangat Penting & $\begin{array}{c}\text { Salah satu elemen Sangat } \\
\text { berpengaruh dan dominasinya } \\
\text { tampak secara nyata. }\end{array}$ \\
\hline 9 & $\begin{array}{c}\text { Mutlak Lebih } \\
\text { Penting }\end{array}$ & $\begin{array}{c}\text { Bukti bahwa salahsatu elemen } \\
\text { lebih penting daripada } \\
\text { pasangannya pada tingkat } \\
\text { keyakinan tertinggi. }\end{array}$ \\
\hline Kebalikan & $\begin{array}{c}\text { Nilai tengah } \\
\text { Diantara } \\
\text { judgement diatas }\end{array}$ & $\begin{array}{c}\text { Nilai ini diberikan jika terdapat } \\
\text { keraguan diantara } 2 \text { penilaian } \\
\text { yang berdekatan }\end{array}$ \\
\hline $\begin{array}{c}\text { aij = 1/aij (jika untuk aktivitas I mendapat satu angka } \\
\text { bila dibandingkan dengan aktivitas j maka j } \\
\text { mempunyai nilai kebalikannya dibanding i. }\end{array}$ \\
\hline
\end{tabular}

- Perhitungan Konsistensi Penilaian

Penilaian AHP dilakukan berdasarkan pengalama dan pemahaman yang bersifat kuantitatif dan subyektif sehingga memungkinkan adanya penilaian yang menyimpang dari konsistensi logis. Pada matriks yang konsisten secara praktis $\lambda$ maks $=$ $\mathrm{n}$, sedang pada matriks yang tidak konsisten maka harus dihitung CI (Consistency Index).

- Perhitungan Nilai Performa

Perhitungan nilai performa dimulai dari hirarki tingkat terbawah sampai dengan hirarki teratas (goal). Nilai performa ini didapat dari hasil mengalikan hasil pengukuran dengan bobot variable/kriteria pengukuran (disebut dengan nilai indeks yang didapatkan dari perbandingan antara data dengan data terbaik). Nilai performa dihitung dengan rumus

$$
P=\sum_{t=1}^{n} Q t, Y T
$$

Dimana :

$\mathrm{Qi}=$ bobot masing-masing elemen (Q1,Q2,...,Qn) $\mathrm{Yi}=$ nilai pengukuran untuk elemen/kriteria dalam suatu sub sistem hirarki adalah $(\mathrm{Y} 1, \mathrm{Y} 2, \ldots . . \mathrm{Yn})$. Proses perhitungan yang sama diteruskan sampa diperoleh nilai performa sistem keseluruhan.

\subsection{Evaluasi dan Seleksi Supplier}

Kriteria evaluasi dan seleksi supplier untuk bahanbaku pengemas yang digunakan di PT. Aneka Tuna Indoesia adalah menggunakan metode AHP yang multi kriteria (finansial dan non finansial) dan mengacupada model QQCD, dimana terdapat empat criteria yaitu : Quantity,Quality, Cost, Delivery.

a. Quality.

Kriteria ini menilai supplier dari segi kualitasterhadap produk yang dihasilkan oleh supplier makakualitas material dari supplier harus menjadipengawasan yang utama demi menghasilkan produkyang bermutu.Yang termasuk dalam kriteria ini adalah : 
- Kesesuaian barang dengan spesifikasi yang sudah ditetapkan

- Penyediaan barang tanpa cacat

b. Quantity.

Yang termasuk dalam kriteria ini adalah :

- Ketepatan dan kesesuaian jumlah dalam setiap pengiriman

\section{c. Cost/harga}

Yang termasuk kriteria harga adalah :

- Kepantasan harga dengan kualitas barang yang dihasilkan dibandingkan dengan harga dari kompetitorlain.

- Kemampuan untuk memberikan potongan harga (diskon) pada pemesanan dalam jumlah tertentu

\section{d. Delivery.}

Yang termasuk dalam kriteria ini adalah :

- Kemampuan untuk mengirimkan barang sesuai dengan tanggal yang telah disepakati

\section{Penetapan Indikator Kinerja Supplier Tiap}

Kriteria

Indikator kinerja supplier (supplier performance indicator) dari masing-masing kriteria diperoleh dari evaluasi data yang selama ini sudah ada di perusahaan dan rumus perhitungannya adalah

1. Quality/kualitas barang datang

$\Sigma$ barang datang diterima $\mathrm{X}$ $100 \%$

$\Sigma$ total barang datang periode tsb.

2. Quantity/jumlah barang datang

$\begin{array}{ll}\Sigma \text { barang datang } & \times 100 \% \\ \Sigma \text { order periode tsb. } & \end{array}$

3. Delivery time/ketepatan waktu pengiriman

$\Sigma$ aktual barang datang tepat waktu

$\mathrm{X}$ $100 \%$

$\Sigma$ rencana barang datang periode tsb.

4. Cost/harga barang
Penawaran harga yang masuk dengan harga yang paling kompetitf maka akan mendapatkan nilai yang tinggi.

\section{Penetapan bobot indikator kinerja supplier}

Penentuan kriteria yang telah dilakukan oleh PT. XX merupakan tahap awal untuk penentuan dari pembobotan masing - masing kriteria dari kinerja supplier.

\section{A. Range Nilai}

Berikut merupakan tabel range nilai untuk supplier yang telah dilakukan

Tabel 4.2 Range Nilai

\begin{tabular}{|c|c|c|c|}
\hline No. & Parameter & Penilaian & Range Nilai \\
\hline 1. & Quality & $0 \%$ Toleransi selama periode evaluasi & 10 \\
\hline & & $25 \%$ Toleransi selama periode evaluasi & 7,5 \\
\hline & & $50 \%$ Toleransi selama periode evaluasi & 5 \\
\hline & & $100 \%$ Toleransi selama periode evaluasi & 2,5 \\
\hline 2. & Quantity & Barang datang sesuai jumlah order & 10 \\
\hline & & Barang datang $\leq 5 \%$ dari jumlah order & 7,5 \\
\hline & & Barang datang $\leq 10 \%$ dari jumlah order & 5 \\
\hline
\end{tabular}

\begin{tabular}{|c|c|c|c|}
\hline & & Barang datang $\leq 15 \%$ dari jumlah order & 2,5 \\
\hline 3. & Cost (Harga) & Sangat Kompetitive & 10 \\
\hline & & Kompetitive & 7,5 \\
\hline & & Tidang Kompetitive & 5 \\
\hline 4. & Delivery & 0 keterlambatan selama periode evaluasi & 10 \\
\hline & & 1 keterlambatan selama periode evaluasi & 7,5 \\
\hline & & 2 keterlambatan selama periode evaluasi & 5 \\
\hline & & $\geq 3$ keterlambatan selama periode evaluasi & 2,5 \\
\hline
\end{tabular}

\section{B. Range Bobot}

Dari hasil range nilai yang sudah ditentukan maka ditetapkan range bobot yang akan berpengaruh pada hasil keputusan pada akhir penilaian seperti pada tabel berikut :

Tabel 4.3 Range Bobot

\begin{tabular}{|c|c|c|}
\hline \multirow{2}{*}{ Parameter } & \multicolumn{2}{|c|}{ Supplier } \\
\cline { 2 - 3 } & Lama & Baru \\
\hline Delivery & $30 \%$ & $35 \%$ \\
\hline Quality & $40 \%$ & $45 \%$ \\
\hline Quantity & $20 \%$ & $15 \%$ \\
\hline Harga & $10 \%$ & $5 \%$ \\
\hline
\end{tabular}




\section{Keputusan Penilaian}

Setelah dilakukan penilaian berdasarkan bobot nilai dan bobot range maka akan diambil suatu keputusan apakah supplier tersebut merupakan supplier pilihan atau harus di keluarkan dari daftar supplier terpilih. Berikut adalah tabel keputusan penilaian evaluasi kinerja supplier :

Tabel 4.4 Kriteria nilai Keputusan

\begin{tabular}{|c|c|c|}
\hline No. & Range Nilai & Keputusan \\
\hline 1. & Total Nilai $9.0-10$ & Supplier Unggulan \\
\hline 2. & Total Nilai $7.1-8.9$ & Tetap Menjadi Supplier \\
\hline 3. & Total Nilai $6.9-7.0$ & Komplain Langsung \\
\hline 4. & Total Nilai $5.1-6.85$ & Surat Komplain \\
\hline 5. & Total Nilai $<5$ & Dikeluarkan dari daftar supplier terpilih \\
\hline
\end{tabular}

Tabel 4.5 Hasil Skor Kinerja Terhadap Supplier

\begin{tabular}{|c|c|c|c|c|c|c|c|}
\hline No. & $\begin{array}{l}\text { Nama } \\
\text { Suplier }\end{array}$ & Produk & Parameter & $\begin{array}{c}\text { Nilai } \\
\text { (N) }\end{array}$ & $\begin{array}{l}\text { Bobot } \\
\text { (B) }\end{array}$ & $\begin{array}{c}\text { Hasil } \\
\text { Nilai } \\
\text { (NxB) }\end{array}$ & $\begin{array}{l}\text { Total } \\
\text { Nilai }\end{array}$ \\
\hline \multirow[t]{4}{*}{1.} & PT. A & Albacor & Delivery & 10 & $30 \%$ & 3 & \multirow{4}{*}{10} \\
\hline & & & Quality & 10 & $40 \%$ & 4 & \\
\hline & & & Quantity & 10 & $20 \%$ & 2 & \\
\hline & & & Harga & 10 & $10 \%$ & 1 & \\
\hline \multirow[t]{4}{*}{2.} & PT. B & Big Eye & Delivery & 7,5 & $30 \%$ & 2,25 & \multirow{4}{*}{8,3} \\
\hline & & & Quality & 10 & $40 \%$ & 4 & \\
\hline & & & Quantity & 7,5 & $20 \%$ & 1.5 & \\
\hline & & & Harga & 10 & $10 \%$ & 1 & \\
\hline \multirow[t]{4}{*}{3.} & PT. C & Bonito & Delivery & 7,5 & $30 \%$ & 2,25 & \multirow{4}{*}{7,25} \\
\hline & & & Quality & 5 & $40 \%$ & 2 & \\
\hline & & & Quantity & 10 & $20 \%$ & 2 & \\
\hline & & & Harga & 10 & $10 \%$ & 1 & \\
\hline
\end{tabular}

\begin{tabular}{|c|c|c|c|c|c|c|c|}
\hline 4. & PT. D & $\begin{array}{l}\text { Skip } \\
\text { Jack }\end{array}$ & Delivery & 5 & $30 \%$ & 1,5 & \multirow{4}{*}{6} \\
\hline & & & Quality & 5 & $40 \%$ & 2 & \\
\hline & & & Quantity & 7,5 & $20 \%$ & 1.5 & \\
\hline & & & Harga & 10 & $10 \%$ & 1 & \\
\hline \multirow[t]{4}{*}{5.} & PT. E & Tongol & Delivery & 2.5 & $30 \%$ & 0.75 & \multirow{4}{*}{5} \\
\hline & & & Quality & 7,5 & $40 \%$ & 3 & \\
\hline & & & Quantity & 5 & $20 \%$ & 1 & \\
\hline & & & Harga & 2,5 & $10 \%$ & 0,25 & \\
\hline
\end{tabular}

Setelah didapatkan hasil nilai dari perhitungan skor kinerja kriteria supplier pada akhirnya akan di dapatkan keputusan mengenai penilaian kinerja supplier seperti pada tabel keputusan berikut ini :
Tabel 4.6 Hasil Keputusan Penilaian Supplier

\begin{tabular}{|c|c|c|c|}
\hline No. & Supplier & Total Nilai & Keputusan \\
\hline 1. & Supplier A & 10 & Supplier Unggulan \\
\hline 2. & Supplier B & 8,3 & Tetap Menjadi Supplier \\
\hline 3. & Supplier C & 7,25 & Tetap Menjadi Supplier \\
\hline 4. & Supplier D & 6 & \begin{tabular}{c} 
Surat komplain \\
\hline 5.
\end{tabular} \\
Supplier E & 5 & $\begin{array}{c}\text { Dikeluarkan dari Daftar Supplier } \\
\text { Terpilih }\end{array}$ \\
\hline
\end{tabular}

Dari hasil keputusan yang didapatkan maka perusahaan akan melakukan tindakan sesuai dengan keputusan penilaian evaluasi kinerja supplier. Apabila keputusannya tetap menjadi suppliyer maka apabila ada order pembelian supplier tersebut tetap akan diberi order tetapi apabila keputusannya dikeluarkan dari daftar supplier terpilih maka supplier tersebut akan dikeluarkan dan tidak diberikan order lagi, apabila supplier tersebut tetap ingin menjadi rekanan maka supplier tersebut akan diperlakukan seperti supplier baru dan akan dilakukan penilaian layaknya supplier yang baru masuk.

\section{Kesimpulan Dan Saran} Kesimpulan

1. Penilaian Evaluasi Kinerja Supplier di perusahaan menggunakan rancangan penilaian dengan menggunakan model Quality, Quantity,Cost, dan Delivery (QQCD) menghasilkan 4 Supplier Performance Indikator (SPI). Kriteria quality memiliki bobot yang tertinggi sebesar $40 \%$, Delivery sebesar 30\% selanjutnya Quantity 20\% dan terakhir adalah cost atau harga sebesar $10 \%$.

2. Dari hasil perhitungan dengan keputusan penilaian kerja supplier dapat dihasilkan ada keputusan yang mana supplier A dengan dengan total nilai 10 dengan keputusan menjadi supplier unggulan, supplier B degan total nilai 8,3 dengan keputusan tetap menjadu supplier, supplier C dengan total nilai 7,25 dengan keputusan tetap menjadi supplier, supplier D dengan total nilai dengan nilai 6 dengan 
keputusan surat protes (complain), dan supplier E dengan total nilai 5 dengan keputusan di eliminasi dari daftar supplier terpilih. Jadi melihat hasil itu semua perusahaan bisa mempertimbangkan lagi tentang pemilihan supplier.

\subsection{Saran}

1. Perusahaan perlu mengkaji bentuk loyalitas dan penghargaan terhadap pemasok bahan baku secara berkala karena behubungan dengan pengembangan produk dan kepuasan pelanggan.

2. Penelitian lanjutan dapat dilakukan untuk mengevaluasi efektivitas dari strategi pemenuhan bahan baku yang diterapkan, sehingga akan ada lebih banyak masukan untuk menjadikan perusahaan memiliki daya saing terutama perusahaan Nasional.

Daftar Pustaka

Eko, Richardus Indrajit \& Djokopranoto,Richardus, 2005, Strategi Manajemen Pembelian dan Supply Chain, PT. Gramedia Widiasarana Indonesia, Jakarta

Hayun, Anggara, 2008, Pemilihan Supplier Folding Box dengan Metode AHP di PT.NIS, ENASE Vol.4 No.2 Januari 2008, ISSN.1829-6378,

Mauizhoh \& Zabidi, 2007, Perancangan Sistem Penilaian dan Seleksi Supplier,Jurnal Ilmiah Teknik Industri Sekolah Tinggi Teknologi Adisutjipto Vol. 5 No. 3 April 2007, hal $113-122$
Putri, Chauliah Fatma, 2007, Analisa Keputusan, Teknik Industri Universitas Widyagama Malang.

Saaty, Thomas L., 1999, Decision Making for Leaders: AHP in a Complex Words, $3^{\text {rd }}$ edition, RWS Publication, Pittsburgh.

Siagian, Yolanda M., 2005, Supply Chain Management: Dalam Dunia Bisnis, PT.Grasindo, Jakarta.

Siagian Y.M. 2005. Aplikasi Suplply Chain Management Dalam Dunia Bisnis. Grasindo, Jakarta.

Tutuarima, T. 2009. Rekayasa Proses Penyulingan Minyak Akar Wangi Dengan Peningkatan Tekanan Dan Laju Uap Bertahap. Tesis Pascasarjana IPB.

Umar, H. 2008. Management Strategic in Action. PT Gramedia Pustaka Utama, Jakarta.

Pujawan, I.N. 2005. Supply Chain Management. Guna Widya, Surabaya.

Saaty, T. L. 1991. Proses Hirarki Analitik untuk Pengambilan Keputusan dalam Situasi yang Kompleks (Terjemahan). PT Pustaka Binaman Pressindo. Jakarta. 
Siagian Y.M. 2005. Aplikasi Suplply Chain

Management Dalam Dunia Bisnis.

Grasindo, Jakarta.

Indrajit, R.E, Djokopranoto R. 2002. Konsep

Manajemen Supply Chain. PT

Gramedia Widiasarana Indonesia,

Jakarta.

Anatan, L. dan Ellitan, L. 2008. Supply Chain

Management, Teori dan Aplikasi.

Bandung: Alfabeta. 
